\title{
Functional $\mu$-Opioid-Galanin Receptor Heteromers in the Ventral Tegmental Area
}

\author{
Estefanía Moreno, ${ }_{1,2}^{1,2}$ César Quiroz, ${ }^{3}$ William Rea, ${ }^{3}$ Ning-Sheng Cai, ${ }^{3}$ - Josefa Mallol, ${ }^{1,2}$ Antoni Cortés, ${ }^{1,2}$ @Carme Lluís, ${ }^{1,2}$ \\ -Enric I. Canela, ${ }^{1,2}$ Vicent Casadó, ${ }^{1,2 *}$ and ${ }^{\circledR}$ Sergi Ferré ${ }^{3 *}$ \\ ${ }^{1}$ Center for Biomedical Research in Neurodegenerative Diseases Network and 2Department of Biochemistry and Molecular Biomedicine, Faculty of Biology, \\ Institute of Biomedicine of the University of Barcelona, University of Barcelona, 08028 Barcelona, Spain, and 3integrative Neurobiology Section, National \\ Institute on Drug Abuse, Intramural Research Program, National Institutes of Health, Baltimore, Maryland 21224
}

The neuropeptide galanin has been shown to interact with the opioid system. More specifically, galanin counteracts the behavioral effects of the systemic administration of $\mu$-opioid receptor (MOR) agonists. Yet the mechanism responsible for this galanin-opioid interaction has remained elusive. Using biophysical techniques in mammalian transfected cells, we found evidence for selective heteromerization of MOR and the galanin receptor subtype Gall (Gal1R). Also in transfected cells, a synthetic peptide selectively disrupted MOR-Gal1R heteromerization as well as specific interactions between MOR and Gal1R ligands: a negative cross talk, by which galanin counteracted MAPK activation induced by the endogenous MOR agonist endomorphin-1, and a cross-antagonism, by which a MOR antagonist counteracted MAPK activation induced by galanin. These specific interactions, which represented biochemical properties of the MOR-GallR heteromer, could then be identified in situ in slices of rat ventral tegmental area (VTA) with MAPK activation and two additional cell signaling pathways, AKT and CREB phosphorylation. Furthermore, in vivo microdialysis experiments showed that the disruptive peptide selectively counteracted the ability of galanin to block the dendritic dopamine release in the rat VTA induced by local infusion of endomorphin-1, demonstrating a key role of MOR-Gal1R heteromers localized in the VTA in the direct control of dopamine cell function and their ability to mediate antagonistic interactions between MOR and GallR ligands. The results also indicate that MOR-Gal1R heteromers should be viewed as targets for the treatment of opioid use disorders.

Key words: dopamine; galanin receptor; MAPK; opioid receptor; receptor heteromer; ventral tegmental area

\section{Significance Statement}

The $\mu$-opioid receptor (MOR) localized in the ventral tegmental area (VTA) plays a key role in the reinforcing and addictive properties of opioids. With parallel in vitro experiments in mammalian transfected cells and in situ and in vivo experiments in rat VTA, we demonstrate that a significant population of these MORs form functional heteromers with the galanin receptor subtype Gall (GallR), which modulate the activity of the VTA dopaminergic neurons. The MOR-GallR heteromer can explain previous results showing antagonistic galanin-opioid interactions and offers a new therapeutic target for the treatment of opioid use disorder.

\section{Introduction}

Opioid use disorders constitute a renewed societal problem with an increasing demand of alternatives to the prevalent substitution therapy with opioid receptor ligands. The $\mu$-opioid receptor

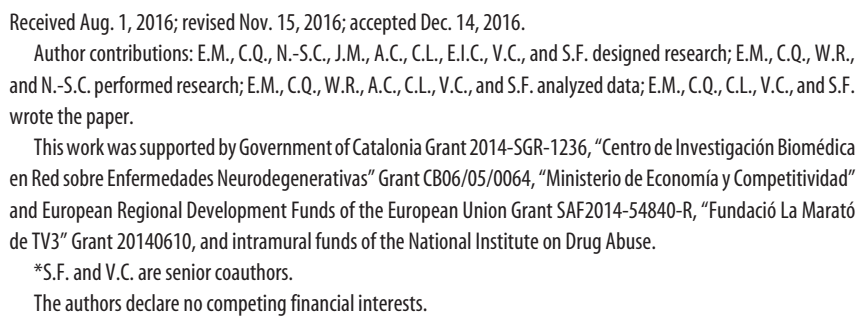

This work was supported by Government of Catalonia Grant 2014-SGR-1236, “Centro de Investigación Biomédica en Red sobre Enfermedades Neurodegenerativas" Grant CB06/05/0064, "Ministerio de Economía y Competitividad" and European Regional Development Funds of the European Union Grant SAF2014-54840-R, "Fundació La Marató de TV3" Grant 20140610, and intramural funds of the National Institute on Drug Abuse.

*S.F. and V.C. are senior coauthors.

The authors declare no competing financial interests.

(MOR) is essential for the analgesic and reinforcing effects of opioids (Matthes et al., 1996). It is well established that MOR localized in the striatum and in the ventral midbrain are involved in the reinforcing effects of opioids (Wise, 1989; McBride et al., 1999; Zangen et al., 2002; Jhou et al., 2012). In the ventral midbrain, endogenous and exogenous MOR agonists activate dopa-

\footnotetext{
Correspondence should be addressed to either of the following: Dr. Sergi Ferré, Integrative Neurobiology Section National Institute on Drug Abuse, Intramural Research Program, Triad Technology Building, 333 Cassell Drive, Baltimore, Maryland 21224, E-mail: sferre@intra.nida.nih.gov; or Dr. Vicent Casadó, Department of Biochemistry and Molecular Biomedicine, Faculty of Biology, University of Barcelona, Diagonal 643, 08028 Barcelona, Spain, E-mail:vcasado@ub.edu.

DOI:10.1523/JNEUROSCI.2442-16.2016

Copyright $\odot 2017$ the authors $\quad 0270-6474 / 17 / 371176-11 \$ 15.00 / 0$
} 
minergic cells in the ventral tegmental area (VTA), which depends primarily on a local MOR-mediated inhibition of tonic GABAergic neurotransmission (Spanagel et al., 1992; Chefer et al., 2009; Barrot et al., 2012; Cui et al., 2014; Matsui et al., 2014) and also possibly on a direct activation of MOR localized on dopaminergic cells that activate voltage-dependent calcium channels (Margolis et al., 2014).

A number of neuropeptides, such as orexin, neuopeptide $\mathrm{Y}$, melanocyte stimulating hormone, and galanin, provide internal signals that are integrated in the brain homeostatic center, the hypothalamus, to regulate the learning and elicitation of foodassociated behaviors. This is not only related to their indirect influence on the ascending dopaminergic system, conveyed by the large lateral hypothalamic efferent connection to the VTA (Faget et al., 2016), but also by their direct influence on neuropeptide receptors localized in the soma and/or dendrites of the dopaminergic cells or in the terminals of their excitatory or inhibitory afferents (Palmiter, 2007; Volkow et al., 2011). This provides the frame for the overlap in the mechanisms involved in substance use disorders and loss of control of food intake and for introducing neuropeptide receptors as targets for both conditions (Palmiter, 2007; Volkow et al., 2011; DiLeone et al., 2012; Boughton and Murphy, 2013).

Several studies indicate the existence of antagonistic interactions between the galanin and opioid systems. Central infusion of galanin attenuates morphine place preference (Zachariou et al., 1999). Furthermore, galanin knock-out mice demonstrate increased locomotion and place preference after acute morphine administration and increased signs of opioid withdrawal after repeated morphine administration, which is counteracted by the systemic administration of the nonpeptidergic, nonselective galanin receptor agonist galnon (Zachariou et al., 2003; Hawes et al., 2008). In addition, genetic studies have found associations of galanin gene polymorphisms with susceptibility to opioid use disorder (Levran et al., 2008; Beer et al., 2013). The most significant association was observed for the single nucleotide polymorphism rs948854, localized in the promoter region (Beer et al., 2013).

Three galanin receptor subtypes so far have been identified: $\mathrm{Gal}_{1}, \mathrm{Gal}_{2}$, and $\mathrm{Gal}_{3}$ (GallR, Gal2R, and Gal3R). Gal1R and Gal2R are the most widespread in the brain, but the lack of specific antibodies and ligands preclude their precise neuronal localization (Hawes and Picciotto, 2005; Lang et al., 2015). It has therefore been difficult to unequivocally establish the localization of galanin receptors and the receptor mechanisms controlling the effects of opioids (Picciotto, 2008). Based on the reported ability of galanin to control MOR-mediated signaling in the VTA (Hawes et al., 2008) and the well established localization of MOR and possible localization of galanin receptors in the VTA (Picciotto, 2008), the present study aimed at evaluating the existence of direct intermolecular and functional interactions between MOR and galanin receptors in the VTA that could locally control dopamine cell function. We first demonstrate that MOR heteromerizes with GallR in mammalian transfected cells, and we disclose specific biochemical properties of the heteromer by using a synthetic peptide that selectively disrupts MOR-Gal1R heteromerization. MOR-GallR heteromers in the VTA could then be demonstrated by identification of the same biochemical properties in situ, with their ability to influence several signaling pathways. More importantly, the use of the disruptive peptide with in vivo microdialysis experiments allowed demonstrating a key role of MOR-Gal1R heteromers localized in the VTA in the direct control of dopamine cell function and their ability to mediate antagonistic interactions between MOR and Gal1R ligands.

\section{Materials and Methods}

Expression vectors and fusion proteins. For bioluminescence resonance energy transfer (BRET) experiments, to obtain receptors fused to Renilla luciferase (Rluc) or to yellow fluorescence protein (YFP), human cDNAs for MOR, Gal1R, Gal2R, GABA ${ }_{\mathrm{B} 2}$ receptor (GABAB2R), or serotonin $5 \mathrm{HT}_{2 \mathrm{~B}}$ receptor (5HT2BR) cloned into pcDNA3.1 were amplified without their stop codons using sense and antisense primers harboring the following: EcoRI and BamHI sites to clone 5HT2BR and EcoRV and KpnI sites to clone MOR in pcRLuc-N1 vector ( $\mathrm{p} R L u c-\mathrm{N} 1$; PerkinElmer); EcoRI and KpnI or BamHI sites to clone GallR or GABAB2R, respectively, in pEYFP-N1 vector (enhanced yellow variant of GFP; Clontech); and HindIII and KpnI sites to clone Gal $_{2} \mathrm{R}$ in pEYFP-N1 vector. Amplified fragments were subcloned to be in-frame with restriction sites of pRLuc-N1 or pEYFP-N1 vectors to provide plasmids that express proteins fused to Rluc or YFP on the C-terminal end (MOR-Rluc, 5HT2BR-Rluc, Gal1R-YFP, Gal2R-YFP, or GABAB2R-YFP). For bimolecular fluorescence complementation (BiFC) experiments, sequences encoding amino acid residues 1-155 and 156-238 of the Venus variant of YFP were subcloned in pcDNA3.1 vector to obtain complementary Venus hemitruncated proteins. Then human cDNA for MOR was subcloned into pcDNA3.1-nYFP to provide a plasmid that expresses the receptor fused to the hemitruncated nVenus-YFP on the C-terminal end of the receptor (MOR-nYFP), and human cDNA for Gal1R and Gal2R was also subcloned into pcDNA3.1-cYFP to provide a plasmid that expresses the receptor fused to the hemitruncated cVenus-YFP on the C-terminal end of the receptor (Gal1R-cYFP, Gal2R-cYFP).

TAT-TM peptides. Peptides, with the sequence of transmembrane (TM) domains of a G-protein-coupled receptor (GPCR) fused to the cellpenetrating HIV transactivator of transcription (TAT) peptide, were used as heteromer-disrupting agents. TAT-TM peptides can be inserted effectively into the plasma membrane as a result of both the penetration capacity of the TAT peptide and the hydrophobic property of the TM domain (He et al., 2011). To obtain the right orientation of the inserted peptide, TM1, TM5, and TM7 of MOR were synthesized with the TAT sequence localized in the C terminus of the corresponding TM (Genemed Synthesis). Peptide sequences for MOR TAT-TM1, MOR TAT-TM5, and MOR TAT-TM7 were MVTAITIMALYSIVCVVGLFGNFLVMYVIVYGRKKRRQRRR, CVFI FAFIMPVLIITVCYGLMILGRKKRRQRRR, and TFQTVSWHFCIAL GYTNGRKKRRQRRR, respectively.

Cell culture and transient transfection. Human embryonic kidney (HEK-293T) cells obtained from ATCC were grown in DMEM (Life Technologies) supplemented with $2 \mathrm{~mm}$ L-glutamine, $100 \mu \mathrm{g} / \mathrm{ml}$ sodium pyruvate, $100 \mathrm{U} / \mathrm{ml}$ penicillin/streptomycin, MEM nonessential amino acid solution (1:100), and $5 \%(\mathrm{v} / \mathrm{v})$ heat-inactivated fetal bovine serum (all supplements were from Invitrogen). Cells were maintained at $37^{\circ} \mathrm{C}$ in an atmosphere of $5 \% \mathrm{CO}_{2}$. Cells growing in six-well dishes were transiently transfected with the corresponding fusion protein cDNA by the polyethylenimine (PEI; Sigma) method and were incubated $(4 \mathrm{~h})$ with the corresponding cDNA together with PEI $(5 \mathrm{ml} / \mathrm{mg}$ cDNA of $10 \mathrm{~mm}$ $\mathrm{PEI}$ ) and $150 \mathrm{~mm} \mathrm{NaCl}$ in a serum-starved medium. After $4 \mathrm{~h}$, the medium was changed to a fresh complete culture medium. Forty-eight hours after transfection, cells were washed twice in quick succession in HBSS [containing the following (in $\mathrm{mm}$ ): $137 \mathrm{NaCl}, 5 \mathrm{KCl}, 0.34$ $\mathrm{Na}_{2} \mathrm{HPO}_{4} \times 12 \mathrm{H}_{2} \mathrm{O}, 0.44 \mathrm{KH}_{2} \mathrm{PO}_{4}, 1.26 \mathrm{CaCl}_{2} \times 2 \mathrm{H}_{2} \mathrm{O}, 0.4 \mathrm{MgSO}_{4} \times$ $7 \mathrm{H}_{2} \mathrm{O}, 0.5 \mathrm{MgCl}_{2}$, and 10 HEPES, pH 7.4], supplemented with $0.1 \%$ glucose $(\mathrm{w} / \mathrm{v})$, detached, and resuspended in the same buffer. The cell number was controlled by determining the sample protein concentration using a Bradford assay kit (Bio-Rad) with bovine serum albumin (BSA) dilutions as standards.

BiFC. After 48 h, HEK-293T cells transiently cotransfected with the cDNA encoding for the receptor fused to nYFP and the receptor fused to cYFP were treated or not with the indicated TAT-TM peptides $(4 \mu \mathrm{M})$ for $4 \mathrm{~h}$ at $37^{\circ} \mathrm{C}$. Reconstituted YFP expression was quantified by distributing the cells $(20 \mu \mathrm{g}$ of protein) in 96-well microplates (black plates with a transparent bottom; Porvair), and emission fluorescence at $530 \mathrm{~nm}$ was read in a Fluo Star Optima Fluorimeter (BMG Labtech) equipped with a 
A
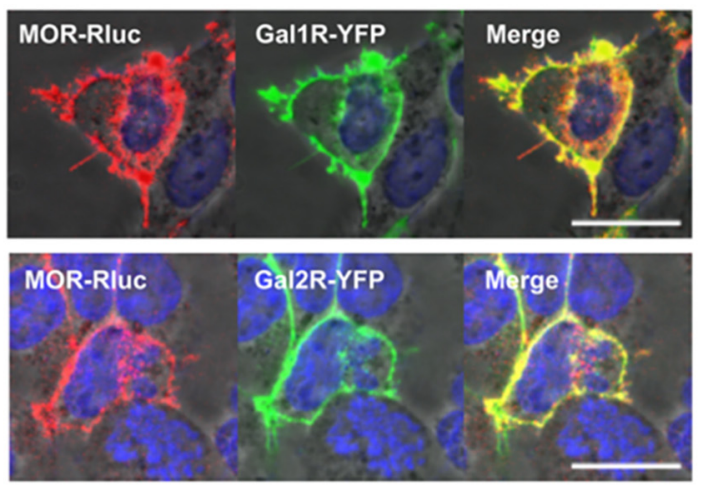

B

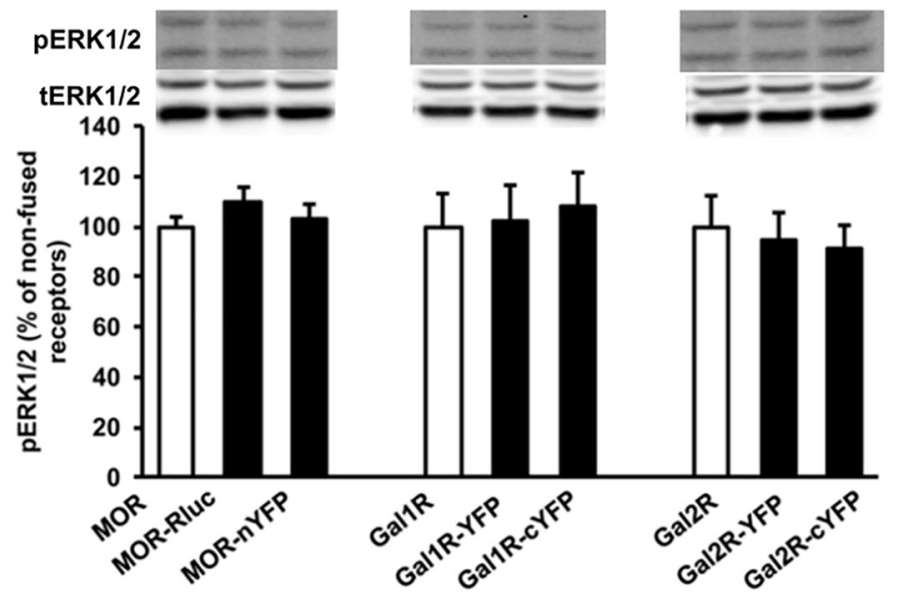

C

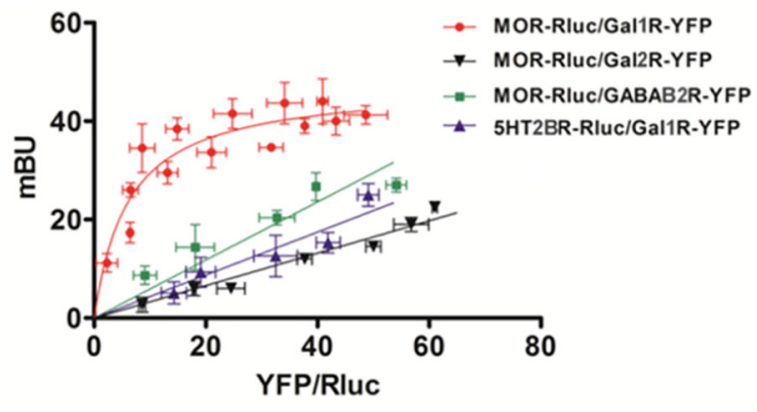

$\mathbf{E}$

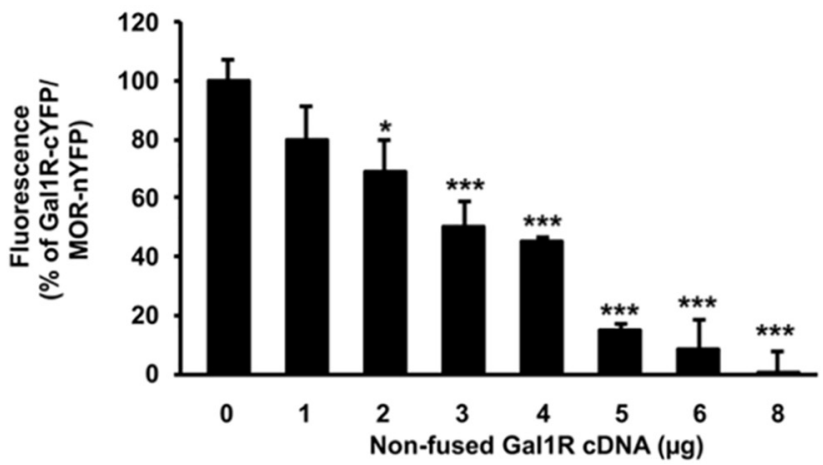

D

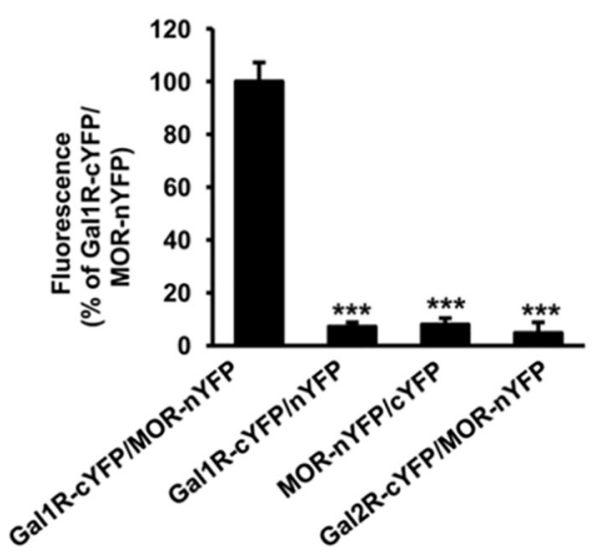

$\mathbf{F}$

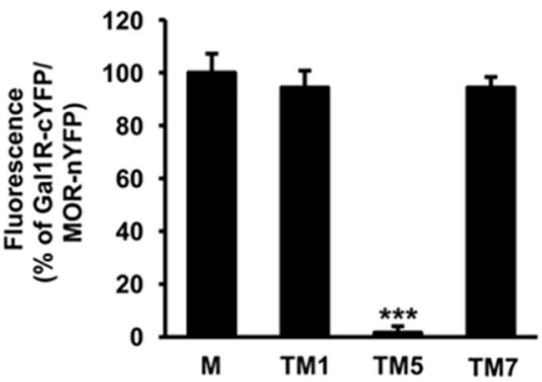

Figure 1. Gal1R-MOR heteromers in transfected HEK-293T cells. $A$, Confocal microscopy images of HEK-293T cells transfected with MOR-Rluc CDNA (0.5 $\mu \mathrm{g}$ ) and Gal1R-YFP or Gal2R-YFP cDNA (1 $\mu \mathrm{g})$. YFP-fused proteins were identified by their own fluorescence (green) and MOR-Rluc by immunocytochemistry (red). Colocalization is shown in yellow (merge). Scale bars, $20 \mu \mathrm{m}$. $\boldsymbol{B}$, ERK1/2 phosphorylation in cells transfected with MOR, MOR-Rluc, or MOR-nYFP CDNA (1 $\mu \mathrm{g})$ and treated with endomorphin-1 (100 nM) or cells transfected with Gal1R, Gal1R-YFP, or Gal1R-CYFP CDNA $(1 \mu \mathrm{g})$ or Gal2R, Gal2R-YFP, or Gal2R-CYFP CDNA (1.2 $\mu \mathrm{g})$ and treated with galanin (100 nm). Values are expressed as means \pm SEM ( $n=4)$ of the percentage of values in cells expressing nonfused receptors; top, representative Western blots. C, BRET saturation experiments in cells transfected with MOR-Rluc CDNA (0.8 $\mu \mathrm{g})$ and increasing amounts of Gal1R-YFP CDNA (0.5-7 $\mu \mathrm{g}$, red curve) or Gal2R-YFP CDNA $(0.2-4 \mu \mathrm{g}$, black line) or, as negative controls, with MOR-Rluc CDNA (0.8 $\mu \mathrm{g})$ and increasing amounts of GABAB2R-YFP CDNA (0.3-3 $\mu \mathrm{g}$, green line) or with serotonin 5-HT2BR-Rluc CDNA (1 $\mu \mathrm{g})$ and increasing amounts of Gal 1 R-YFP CDNA (0.5-5 $\mu \mathrm{g}$, blue line). The relative amount of BRET is obtained as a function of 100 times the ratio between the fluorescence of the acceptor (YFP) and the luciferase activity of the donor (Rluc). BRET is expressed as milliBRET units and is expressed as the mean \pm SD $(n=3-6)$ grouped as a function of the amount of BRET acceptor. D, Fluorescence complementation experiments in cells transfected with Gal1 R-cYFP and MOR-nYFP, Gal2R-CYFP and MOR-nYFP, Gal1R-CYFP and nonfused nYFP, or nonfused cYFP and MOR-nYFP cDNA (4 $\mu \mathrm{g}$ in all cases). Values are expressed as means \pm SEM ( $n=3-6)$ of the percentage of values in cells not expressing Gal1R (100\%: 15,000 fluorescence units). $\boldsymbol{E}$, Fluorescence complementation experiments in cells transfected with Gal ${ }_{1} \mathrm{R}-\mathrm{CYFP}$ and MOR-nYFP CDNA $(4 \mu \mathrm{g})$ and increasing amounts $(0-8 \mu \mathrm{g})$ of nonfused Gal ${ }_{1} R$ CDNA. Values are expressed as means \pm SEM $(n=3-6)$ of the percentage of values in cells not expressing Gal1R (100\%: 15,000 fluorescence units). F, Fluorescence complementation experiments in cells transfected with Gal1R-cYFP and MOR-nYFP cDNA (4 $\mu \mathrm{g})$ and incubated for $4 \mathrm{~h}$ with MOR TAT-TM1, MOR TAT-TM5, or MOR TAT-TM7 peptides $(4 \mu \mathrm{M})$ or with medium (M). Values are expressed as means \pm SEM $(n=3-6)$ of the percentage of fluorescence in untreated cells (100\%: 15,000 fluorescence units). Statistical differences in $\boldsymbol{D}-\boldsymbol{F}$ were analyzed by one-way ANOVA followed by Newman-Keuls multiple comparison tests; ${ }^{*} p<0.05$ and ${ }^{* * *} p<0.001$, compared with cells expressing Gal1R-CYFP and MOR-nYFP, in the absence of nonfused Gal1R or without incubation with TAT peptides. 
A

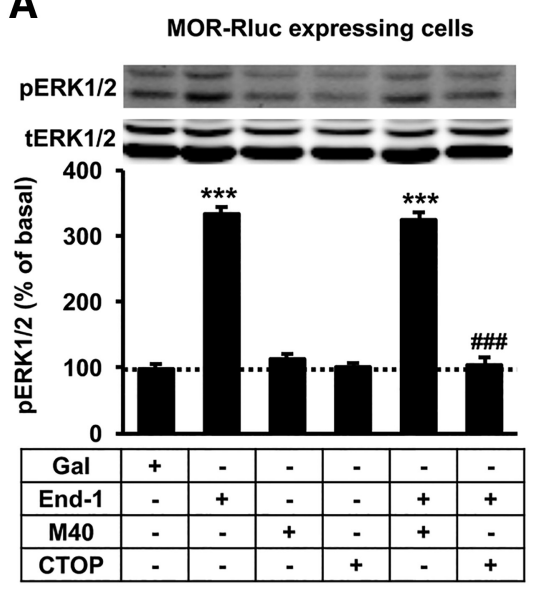

B

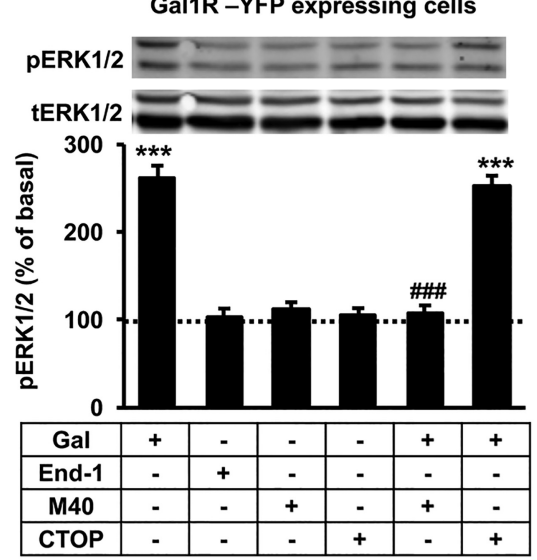

Figure 2. Selectivity of Gal1R and MOR ligands. ERK1/2 phosphorylation was determined in HEK-293T cells transfected with MOR-Rluc CDNA $(\boldsymbol{A} ; 1.2 \mu \mathrm{g})$ or with Gal1R-YFP CDNA $(\boldsymbol{B} ; 2 \mu \mathrm{g})$. Cells were preincubated for 20 min with medium, the MOR antagonist CTOP $(10 \mu \mathrm{M})$, or the Gal1R antagonist M40 $(10 \mu \mathrm{M})$ and treated for 12 min with medium, galanin (Gal, $100 \mathrm{nM})$, or endomorphin-1 (End-1, $100 \mathrm{nm)}$ ); top, representative Western blots. Values are expressed as means $\pm \operatorname{SEM}(n=4)$ of the percentage of values in untreated cells (dotted lines). Statistical differences were analyzed by one-way ANOVA followed by Newman-Keuls multiple comparison tests; ${ }^{* *} p<0.001$ and ${ }^{\# \# \#} p<0.001$, compared with untreated cells or with cells treated with the corresponding agonist alone, respectively.

high-energy xenon flash lamp, using a $10 \mathrm{~nm}$ bandwidth excitation filter at $400 \mathrm{~nm}$ reading. Protein fluorescence expression was determined as the fluorescence of the sample minus the fluorescence of cells not expressing the fusion proteins (basal). Cells expressing GallR-cYFP and nYFP or MOR-nYFP and cYFP showed similar fluorescence levels to nontransfected cells.

BRET. HEK-293T cells were transiently cotransfected with a constant amount of expression vector encoding for receptor fused to Rluc and with increasing amounts of the expression vector corresponding to receptor fused to YFP. Protein-YFP expression was quantified by distributing cells $(20 \mu \mathrm{g}$ of protein, around 4000 cells/well $)$ in 96-well microplates (black plates with a transparent bottom), and fluorescence was read in a Fluo Star Optima Fluorimeter (BMG Labtech), equipped with a high-energy xenon flash lamp, using a $10 \mathrm{~nm}$ bandwidth excitation filter at $400 \mathrm{~nm}$ reading. Protein fluorescence expression was determined as the fluorescence of the sample minus the fluorescence of cells expressing the receptor-Rluc alone. For BRET measurements, the equivalent of $20 \mu \mathrm{g}$ of cell suspension were distributed in 96-well microplates (Corning 3600, white plates; Sigma) and $5 \mu \mathrm{M}$ coelenterazine $\mathrm{H}$ (Invitrogen) was added. After $1 \mathrm{~min}$, readings were collected using a Mithras LB 940 late reader (Berthold Technologies) that allows the integration of the signals detected in the short-wavelength filter at $485 \mathrm{~nm}(440-500 \mathrm{~nm})$ and the long-wavelength filter at $530 \mathrm{~nm}(510-590 \mathrm{~nm})$. To quantify receptor-Rluc expression, luminescence readings were also performed after $10 \mathrm{~min}$ of adding $5 \mu \mathrm{m}$ coelenterazine $\mathrm{H}$. Fluorescence and luminescence of each sample were measured before every experiment to confirm similar donor expressions ( $\sim 100,000$ bioluminescence units) while monitoring the increase in acceptor expression (1000-40,000 fluorescence units). The net BRET was defined as [(long-wavelength emission)/ (short-wavelength emission)]-cf., where cf. corresponds to [(longwavelength emission)/(short-wavelength emission)] for the receptorRluc expressed alone in the same experiment. BRET is expressed as milliBRET units $(\mathrm{mBU}$; net BRET $\times 1000)$. Data were fitted to a nonlinear regression equation, assuming a single-phase saturation curve with GraphPad Prism software.

Immunodetection assays. Cells were fixed in 4\% paraformaldehyde for 15 min and washed with PBS containing $20 \mathrm{~mm}$ glycine (buffer A) to quench the aldehyde groups. After permeabilization with buffer A containing $0.2 \%$ Triton X-100 for $5 \mathrm{~min}$, cells were treated with PBS containing $1 \%$ of BSA. After $1 \mathrm{~h}$ at room temperature, cells were labeled with the primary mouse monoclonal anti-RLuc receptor antibody (1:200; Millipore) for $1 \mathrm{~h}$ to detect MOR-Rluc, washed, and stained with the secondary Cy3 donkey anti- mouse antibody (1:200; Jackson ImmunoResearch). Gal1R or Gal2R fused to YFP protein was detected by its fluorescence properties. The samples were rinsed several times and mounted with a medium suitable for immunofluorescence (30\% Mowiol; Calbiochem). Samples were observed in a Leica SP2 confocal microscope.

Rat VTA slices preparation. Male Sprague Dawley rats (2 months old; animal facility of the Faculty of Biology, University of Barcelona) were used. The animals were housed two per cage and kept on a $12 \mathrm{~h}$ dark/light cycle with food and water available ad libitum, and experiments were performed during the light cycle. All procedures were approved by the Catalan Ethical Committee for Animal Use (CEAA/DMAH 4049 and 5664). Animals were killed by decapitation under $4 \%$ isoflurane anesthesia, and brains were rapidly removed, placed in ice-cold oxygenated $\left(\mathrm{O}_{2} / \mathrm{CO}_{2}, 95 \% /\right.$ $5 \%$ ) Krebs $-\mathrm{HCO}_{3}^{-}$buffer (in mM: $124 \mathrm{NaCl}, 4$ $\mathrm{KCl}, 1.25 \mathrm{KH}_{2} \mathrm{PO}_{4}, 1.5 \mathrm{MgCl}_{2}, 1.5 \mathrm{CaCl}_{2}, 10$ glucose, and $26 \mathrm{NaHCO}_{3}, \mathrm{pH} 7.4$ ), and sliced at $4^{\circ} \mathrm{C}$ using a brain matrix (Zivic Instruments). VTA slices $(500 \mu \mathrm{m}$ thick) were dissected at $4^{\circ} \mathrm{C}$ in Krebs $-\mathrm{HCO}_{3}^{-}$buffer; each slice was transferred into a 12 -well plate with Corning Netwell inserts containing $2 \mathrm{ml}$ of ice-cold Krebs $-\mathrm{HCO}_{3}^{-}$buffer. The temperature was raised to $23^{\circ} \mathrm{C}$, and after 30 $\mathrm{min}$, the medium was replaced by $2 \mathrm{ml}$ of fresh buffer $\left(23^{\circ} \mathrm{C}\right)$. Slices were incubated under constant oxygenation $\left(\mathrm{O}_{2} / \mathrm{CO}_{2}, 95 \% / 5 \%\right)$ at $30^{\circ} \mathrm{C}$ for $4 \mathrm{~h}$ in an Eppendorf Thermomixer (5 PRIME), and the medium was replaced by fresh buffer and incubated for $30 \mathrm{~min}$ before the addition of any agent. After incubation, the solution was discarded, and slices were frozen on dry ice and stored at $-80^{\circ} \mathrm{C}$ until ERK1/2 phosphorylation was determined.

Determination of phosphorylated ERK1/2, AKT, and CREB in cells or in VTA tissue. Transfected HEK-293T cells were cultured in serum-free medium for $16 \mathrm{~h}$ before the addition of any agent. Cells or rat VTA slices were treated or not with the indicated ligands for the indicated time and were lysed by the addition of $300 \mu$ lof ice-cold lysis buffer $(50 \mathrm{~mm}$ Tris- $\mathrm{HCl}$, pH 7.4, $50 \mathrm{~mm} \mathrm{NaF}, 150 \mathrm{~mm} \mathrm{NaCl}, 45 \mathrm{~mm} \beta$-glycerophosphate, $1 \%$ Triton X-100, $20 \mu \mathrm{M}$ phenyl-arsine oxide, $0.4 \mathrm{~mm} \mathrm{NaVO}_{4}$, and protease inhibitor mixture). Cellular debris was removed by centrifugation at $13,000 \times g$ for $5 \mathrm{~min}$ at $4^{\circ} \mathrm{C}$, and the protein was quantified by the bicinchoninic acid method using BSA dilutions as standard. Phosphorylated proteins were then determined by Western blot, using a mouse anti-phospho-ERK1/2 antibody (1:2500; Sigma) and rabbit anti-totalERK1/2 antibody (1: 40,000; Sigma) to quantify phospho-ERK1/2 or a rabbit anti-phospho-Ser473-AKT antibody (1:2500; SAB Signalway Antibody) and a mouse anti-total-AKT antibody (1:2500; Cell Signaling) to quantify phospho-AKT or a rabbit anti-phospho-CREB antibody (1: 1000; Abcam) and a mouse anti-total-CREB antibody (1:2000; Millipore) to quantify phosphor-CREB. Bands were visualized by the addition of a mixture of IRDye 800 (anti-mouse) antibody (1:10,000; Sigma) and IRDye 680 (anti-rabbit) antibody (1:10,000; Sigma) and scanned by an Odyssey infrared scanner (LI-COR Biosciences). Band densities were quantified using the scanner software exported to Excel (Microsoft). The level of phosphorylated proteins was normalized for differences in loading using the total (phosphorylated plus nonphosphorylated) protein band intensities.

In vivo microdialysis experiments. Male Sprague Dawley rats (3 months old; Charles River Laboratories) were used. Animals were housed two per cage and kept on a $12 \mathrm{~h}$ dark/light cycle with food and water available ad libitum. Experiments were performed during the light cycle. All animals used in the study were maintained in accordance with the National Institutes of Health Guide for the Care and Use of Laboratory Animals, and the animal research conducted to perform this study was reviewed and approved by the NIDA Intramural Research Program Animal Care and 
A

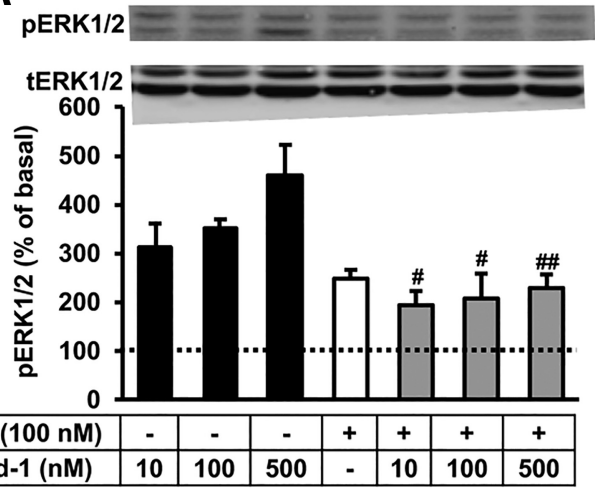

B

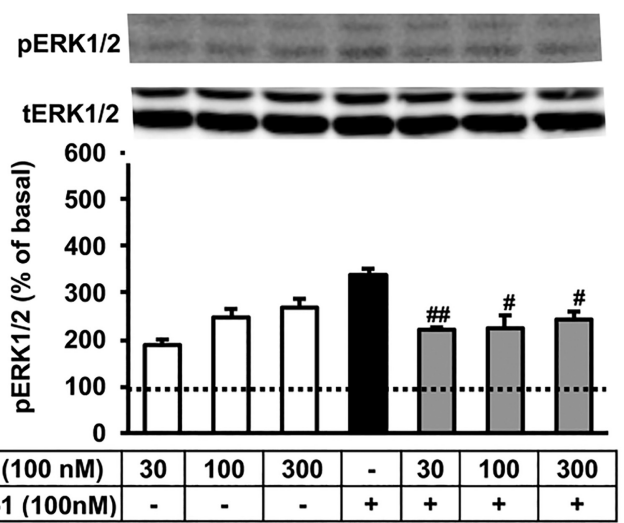

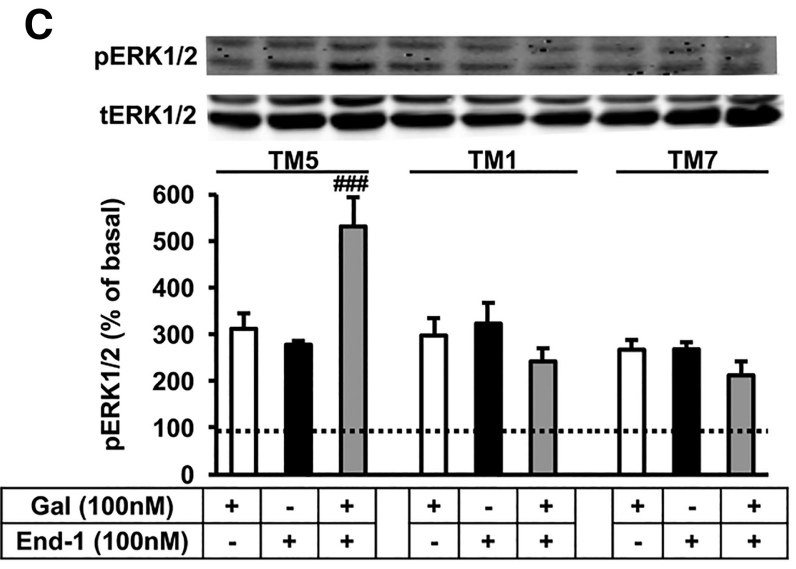

Figure 3. Negative cross talk within the Gal1R-MOR heteromer. ERK1/2 phosphorylation was determined in HEK-293T cells transfected with MOR-Rluc cDNA (1.2 $\mu$ g) and Gal1R-YFP cDNA $(2 \mu \mathrm{g})$. A-C, Cells were treated for $12 \mathrm{~min}$ with the indicated concentrations of endomorphin-1 (End-1), galanin (Gal), or both. C, Cells were previously incubated for $4 \mathrm{~h}$ with M0R TAT-TM1, M0R TAT-TM5, or MOR TAT-TM7 peptides $(4 \mu \mathrm{m})$; top, representative Western blots. Values are expressed as means \pm SEM $(n=4-5)$ of the percentage of values of cells without agonist treatment (dotted lines). Statistical differences were analyzed by one-way ANOVA followed by Newman-Keuls multiple comparison tests; ${ }^{\#} p<0.05,{ }^{\# \#} p<0.01$, and ${ }^{\# \# \# ~} p<0.001$, compared with cells treated with the same concentration of endomorphin-1 alone.

Use Committee (protocol number 15-BNRB-73). Rats were deeply anesthetized with $3 \mathrm{ml} / \mathrm{kg}$ Equithesin (4.44 $\mathrm{g}$ of chloral hydrate, $0.972 \mathrm{~g}$ of Na pentobarbital, $2.124 \mathrm{~g}$ of $\mathrm{MgSO}_{4} 44.4 \mathrm{ml}$ of propylene glycol, $12 \mathrm{ml}$ of ethanol, and distilled $\mathrm{H}_{2} \mathrm{O}$ up to $100 \mathrm{ml}$ of the final solution; NIDA Pharmacy) and implanted unilaterally in the ventral tegmental area (coordinates in millimeters from bregma with a $10^{\circ}$ angle in the coronal plane: anterior, -5.6 ; lateral, 2.4 ; vertical, -9 ) with a specially designed microdialysis probe that allows the direct infusion of large peptides within the sampling area (Navarro et al., 2015). After surgery, rats were allowed to recover in hemispherical CMA-120 cages (CMA Microdialysis) equipped with twochannel overhead fluid swivels (Instech) connected to a sample collector (CMA 470, CMA). Twenty-four hours after implanting the probe, experiments were performed on freely moving rats in the same hemispherical home cages in which they recovered overnight from surgery. An artificial cerebrospinal solution containing (in $\mathrm{mM}$ ) $144 \mathrm{NaCl}, 4.8 \mathrm{KCl}, 1.7 \mathrm{CaCl}_{2}$, and $1.2 \mathrm{MgCl}_{2}$ was pumped through the probe at a constant rate of $1 \mu \mathrm{l} / \mathrm{min}$. After a washout period of $90 \mathrm{~min}$, dialysate samples were collected at $20 \mathrm{~min}$ intervals. For peptide infusion, galanin and endopmorphin- 1 were dissolved in ACSF to a final concentration of $10 \mu \mathrm{M}$, whereas TAT-TM peptides were dissolved in $0.1 \%$ DMSO in ACSF to a final concentration of $60 \mu \mathrm{M}$. All peptides were injected with a $1 \mu \mathrm{l}$ syringe (Hamilton) driven by an infusion pump and coupled with silica tubing (73 $\mu \mathrm{m}$ inner diameter; Polymicro) to the microdialysis probe infusion port (dead volume, $40 \mathrm{nl}$ ), which was primed with ACSF and plugged during implantation. All peptides were delivered at a rate of $16.6 \mathrm{nl} / \mathrm{min}$. At the end of the experiment, rats were given an overdose of Equithesin, the brains were extracted and fixed in formaldehyde, and probe placement was verified using cresyl violet staining. Dopamine content was measured by HPLC coupled with a coulometric detector (5200a Coulochem III; ESA).
Statistics. Parametric statistics (one-way or repeated-measures ANOVA followed by Newman-Keuls multiple comparison tests) were used, since the different groups analyzed showed normality and homogeneity of variance. GraphPad Prism software version 5 was used for the statistical analysis.

\section{Results}

Gal1R but not Gal2R forms heteromers with MOR in transfected mammalian cells

The possibility of intermolecular interactions between Gal1R and Gal2R with MOR was first investigated with a BRET assay, using receptors fused to Rluc or to YFP. These fusion proteins properly trafficked to the cell membrane of transfected HEK-293T cells, and practically all transfected cells showed cotransfection, as shown by confocal microscopy (Fig. $1 A$ ). Fusion proteins were fully functional, as found by comparing their ability to increase ERK1/2 phosphorylation with that of native receptors (Fig. 1B). Although MOR highly colocalized with Gal1R or Gal2R when coexpressed in HEK-293T cells (Fig. 1A), saturable BRET curves were only obtained in cells transfected with a constant amount of MOR-Rluc cDNA and increasing amounts of Gal1R-YFP cDNA (Fig. $1 C$; with BRET $_{\max }$ and BRET $_{50}$ values of $47.5 \pm 3 \mathrm{mBU}$ and $6.2 \pm 1.6$, respectively). In contrast, linear plots were obtained in cells transfected with a constant amount of MOR-Rluc and increasing amounts of Gal2R-YFP cDNA, similar to the negative controls; cells transfected with a constant amount of MORRluc cDNA and increasing amounts of $\mathrm{GABA}_{\mathrm{B} 2}-\mathrm{YFP}$ receptor 
A

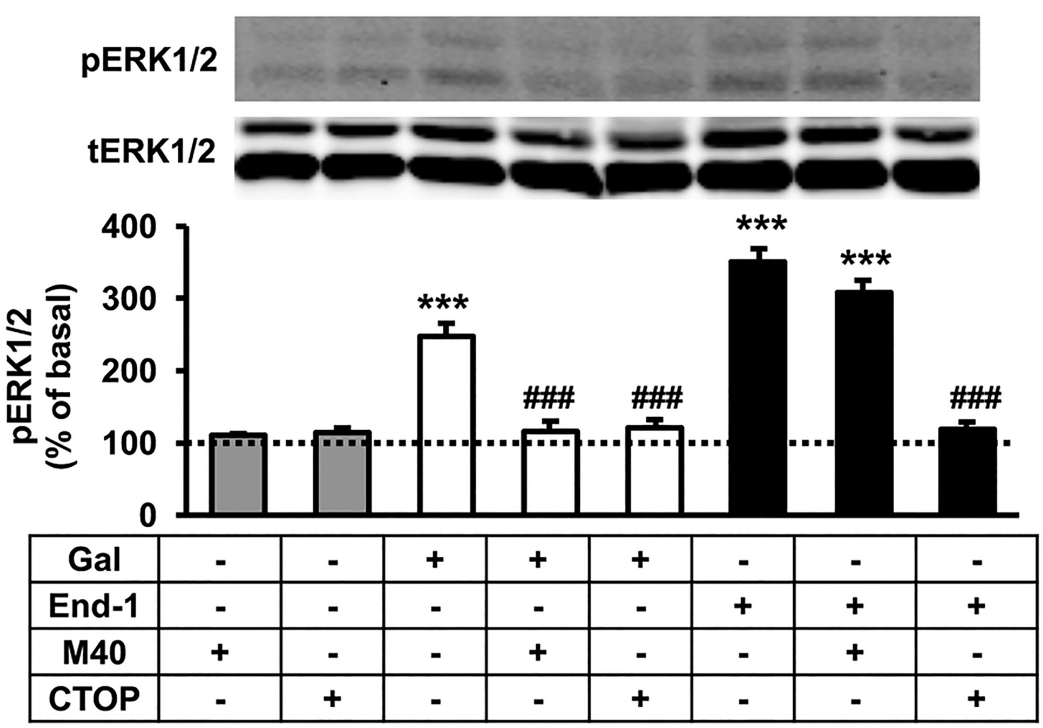

B

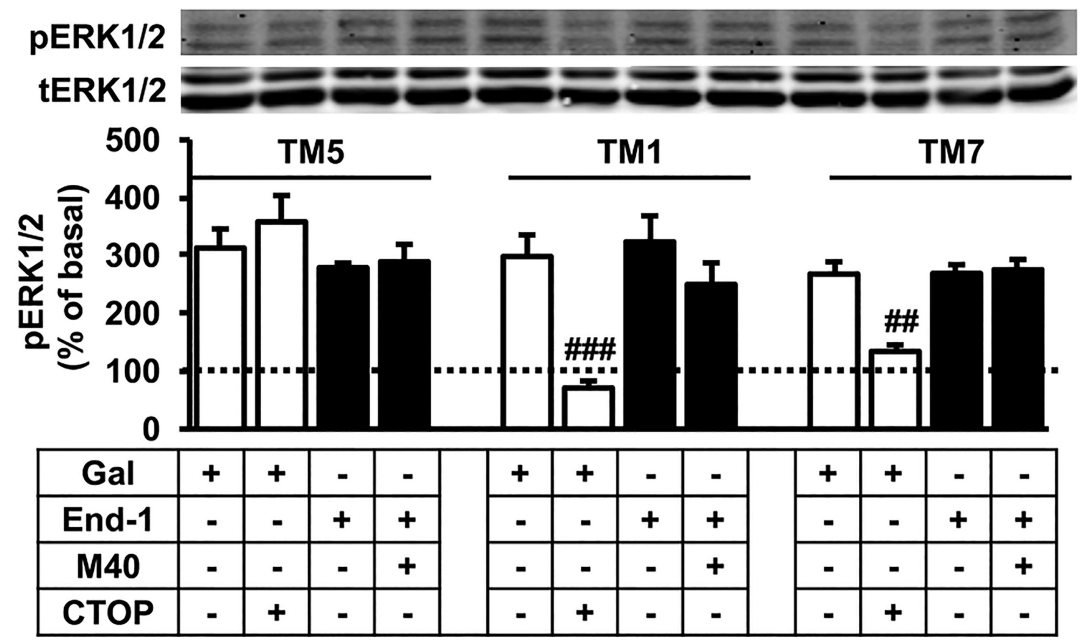

Figure 4. Cross-antagonism within the Gal1R-MOR heteromer. ERK1/2 phosphorylation was determined in HEK-293T cells transfected with MOR-Rluc CDNA $(1.2 \mu \mathrm{g})$ and Gal1R-YFP CDNA $(2 \mu \mathrm{g}) . \boldsymbol{A}, \boldsymbol{B}$, Cells were preincubated for 20 min with medium, the MOR antagonist CTOP $(10 \mu \mathrm{M})$, or the Gal1R antagonist M40 (10 $\mu \mathrm{M})$ and treated for 12 min with medium, galanin (Gal, $100 \mathrm{nM})$,

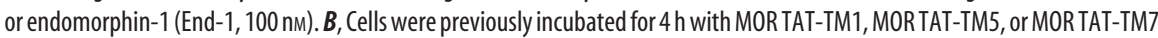
peptides (4 $\mu \mathrm{M})$; top, representative Western blots. Values are expressed as means \pm SEM $(n=3-12)$ of the percentage of values in untreated cells (dotted lines). Statistical differences were analyzed by one-way ANOVA followed by Newman-Keuls multiple comparison tests; ${ }^{* * *} p<0.001$, compared with untreated cells; ${ }^{\# \#} p<0.01$ and ${ }^{\# \# \#} p<0.001$, compared with cells treated with the same agonist administered alone.

cDNA; or a constant amount of serotonin $5 \mathrm{HT}_{2 \mathrm{~B}}$ - $\mathrm{Rluc}$ receptor cDNA and increasing amounts of Gal1R-YFP cDNA (Fig. 1C). These results strongly suggest the specific ability of MOR to heteromerize with Gal1R. Further support for the specificity of MOR-Gal1R heteromerization was obtained by the BiFC assay. In this assay, two complementary halves of YFP (Venus variant; cYFP and nYFP) are separately fused to the two putative interacting receptors. Fluorescence is obtained after reconstitution of functional YFP, when the two receptors come within very close proximity (Guitart et al., 2014; Bonaventura et al., 2015; Navarro et al., 2015). Significant fluorescent values could only be detected in HEK-293T cells cotransfected with Gal1R-cYFP and MORnYFP cDNAs, but not with Gal2R-cYFP and MOR-nYFP (Fig. 1D). As negative controls, cells were transfected with nonfused cYFP and MOR-nYFP or with Gal1R-cYFP and nonfused nYFP (Fig. 1D). Cotransfection with increasing amounts of nonfused GallR pre- vented complementation of Gal1R-cYFP with MOR-nYFP and reduced fluorescence to undetectable values (Fig. $1 E$ ), indicating that MOR-Gal1R heteromerization is not induced by YFP complementation.

Application of disrupting synthetic peptides fused to the HIV-TAT peptides (see Materials and Methods), which interact with the oligomer interface, is providing an effective tool to dissect the properties of GPCR heteromers and to demonstrate their presence in native tissues (He et al., 2011; Guitart et al., 2014; Bonaventura et al., 2015; Navarro et al., 2015; Viñals et al., 2015). A TAT peptide with the amino acid sequence of the transmembrane domain TM1 of the MOR (MOR TAT-TM1) was used, since it was previously reported to destabilize heteromers of MOR with $\delta$-opioid receptor (He et al., 2011). MOR TAT-TM5 and MOR TAT-TM7 were also used, since TM5 has been repeatedly reported to be part of the interface of several GPCR heteromers, whereas TM7 always provides a negative control (Guitart et al., 2014; Bonaventura et al., 2015; Navarro et al., 2015; Viñals et al., 2015). In fact, MOR TAT-TM5, but not MOR TAT-TM7, significantly prevented complementation of Gal1R-cYFP with MOR-nYFP. MOR TAT-TM1 did not significantly modify Gal1R-cYFP-MOR-nYFP complementation (Fig. $1 F$ ). MOR TATpeptides were then used as tools to demonstrate functional properties of the MOR-Gal1R heteromer in HEK-293T cells and to demonstrate its presence and functional significance in the VTA.

Functional characteristics of the Gal1RMOR

A GPCR heteromer is defined as a macromolecular complex composed of at least two (functional) receptor units (protomers) with biochemical properties that are demonstrably different from those of its individual components (Ferré et al., 2009). Among those biochemical properties, a common consequence of GPCR heteromerization is a specific integrated signaling after coactivation of the molecularly different protomers compared with their separate activation (Ferré et al., 2009, 2014; Gomes et al., 2016). In transfected HEK293T cells, we evaluated possible interactions between the endogenous Gal1R and MOR peptidergic agonists galanin (the 29 amino acid rat sequence; Lang et al., 2015) and endomorphin-1 (Tyr-Pro-Trp-Phe- $\mathrm{NH}_{2}$; Zadina et al., 1997) and the effects of the peptidergic nonselective Gal1R-Gal2R receptor antagonist M40 (Gly-Trp-Thr-Leu-Asn-Ser-Ala-Gly-Tyr-Leu-Leu-Gly-Pro-

Pro-Pro-Ala-Leu-Ala-Leu-Ala- $\mathrm{NH}_{2}$; Webling et al., 2012) and the selective MOR antagonist CTOP (D-Phe-Cys-Tyr-D-TrpOrn-Pen-Thr-NH2; Gulya et al., 1988). ERK1/2 phosphorylation (MAPK activation) was used as the cell signaling output since its increase in the VTA has been associated with reinforcing effects of opioids (Hawes et al., 2008). As expected, in cells only transfected 
A

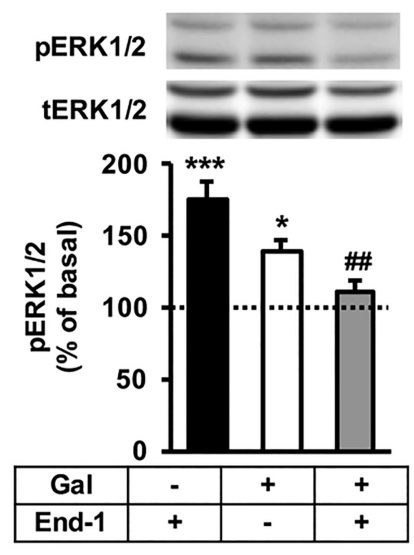

B

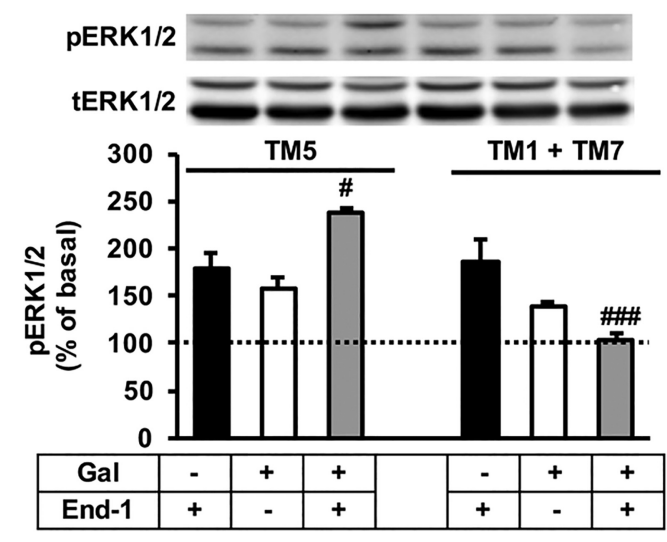

C

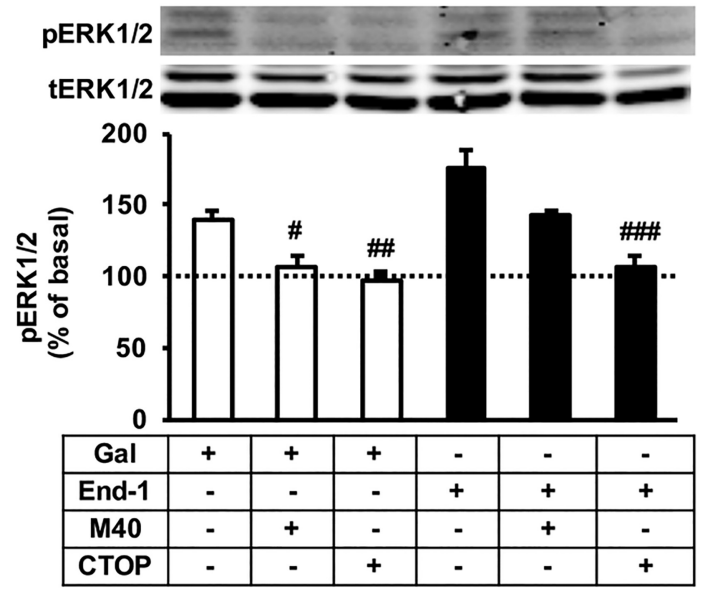

D

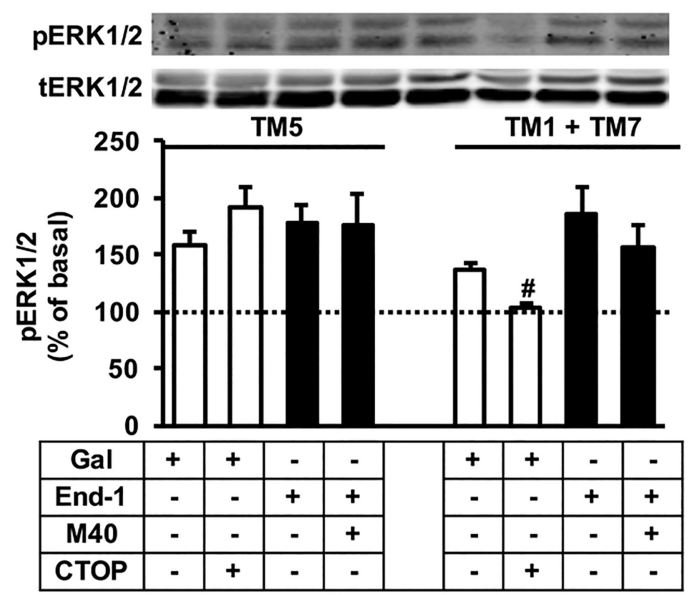

Figure 5. MAPK activation by Gal1R-MOR heteromers in the rat VTA. ERK1/2 phosphorylation was determined in rat VTA slices pretreated for $3 \mathrm{~h}$ with medium $(A, C)$ or $4 \mu \mathrm{M}$ of the MOR TAT-TM5 peptide or both MOR TAT-TM1 and MOR TAT-TM7 peptides $(\boldsymbol{B}, \boldsymbol{D})$. Slices were then incubated for $20 \mathrm{~min}$ with medium, the MOR antagonist CTOP (10 $\mu \mathrm{M})$, or the Gal1R antagonist M40 (10 $\mu \mathrm{M})$ and treated for 12 min with medium, galanin (Gal, $1 \mu \mathrm{M}$ ), endomorphin-1 (End-1, $1 \mu \mathrm{m}$ ), or both; top, representative Western blots. Values are expressed as means \pm SEM (3-5 slices) of the percentage of values in untreated cells (dotted lines). Statistical differences were analyzed by one-way ANOVA followed by Newman-Keuls multiple comparison tests; ${ }^{*} p<0.05$ and ${ }^{* * *} p<0.001$, compared with untreated slices; ${ }^{\#} p<0.05$, ${ }^{\#} p<0.01$, and ${ }^{\# \# \#} p<0.001$, compared with slices only treated with the same concentration of endomorphin-1 or galanin administered alone.

with MOR cDNA, endomorphin-1 but not galanin induced ERK1/2 phosphorylation that was reverted by CTOP but not by M40 (Fig. 2A). Also as expected, in cells only transfected with Gal1R cDNA, galanin but not endomorfin-1 induced ERK1/2 phosphorylation that was reverted by M40 but not CTOP (Fig. $2 B$ ), which demonstrates the specificity of the ligands for their respective receptors.

In cells transfected with both MOR and Gal1R, combined administration of different concentrations of galanin and endomorphin-1 did not produce any additive effect, but the same effect as galanin alone (Fig. $3 A, B$ ). Consequently, galanin significantly counteracted the effect of more effective concentrations of endomorphin-1 (Fig. $3 A, B$ ). This negative cross talk was blocked by incubation of MOR TAT-TM5 peptide, but not MOR TAT-TM1 or MOR TAT-TM7 (Fig. 3C), demonstrating its dependence on MORGal1R heteromerization and, therefore, constituting a biochemical property of the MOR-Gal1R heteromer. An additional biochemical property of the MOR-Ga1R heteromers was observed when combining agonists and antagonists. In HEK-293T cells cotransfected with MOR and Gal1R, the ability of galanin to increase ERK1/2 phosphorylation was not only antagonized by the galanin receptor antagonist M40, but also by the MOR antagonist CTOP (Fig. 4A). This cross-antagonism is a property often described for GPCR het- eromers (Guitart et al., 2014; Bonaventura et al., 2015; Navarro et al., 2015; Viñals et al., 2015). In fact, its dependence on MOR-Gal1R heteromerization was also demonstrated by its selective blockade with the MOR TAT-TM5 peptide, but not MOR TAT-TM1 or MOR TAT-TM7 (Fig. 4B). Cross-antagonism was apparently unidirectional in transfected cells, and M40 counteracted the effect of galanin but not endomorphin-1 (Fig. 4A).

Functional Gal1R-MOR heteromers in the VTA locally modulate ERK1/2, AKT and CREB phosphorylation and dendritic dopamine release

It has been previously documented from ex vivo experiments that systemic morphine administration induces ERK1/2 phosphorylation (MAPK activation) in the VTA (Valjent et al., 2004; Hawes et al., 2008), which, however, did not imply a direct activation of MOR localized in the VTA. To better analyze the role of local interactions of MOR and galanin receptors within the VTA, we first measured in situ ERK1/2 phosphorylation, and also AKT and CREB phosphorylation, in rat VTA slices exposed to selective ligands (a method previously described by Navarro et al., 2015). As in previous studies, higher ligand concentrations were used compared with transfected cell preparations to allow sufficient penetration into the tissue (Bonaventura et al., 2015; Navarro et al., 
A

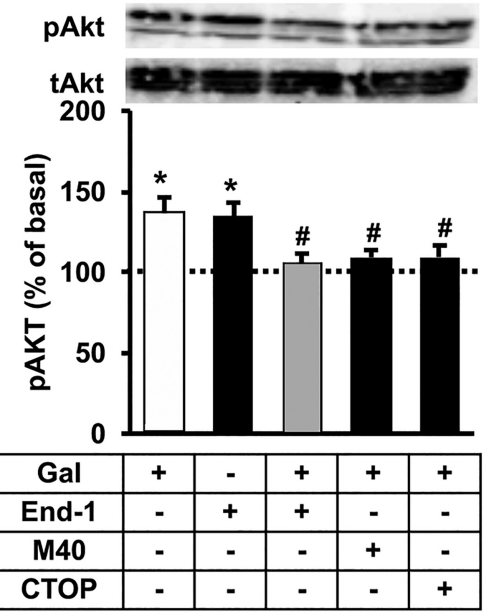

B

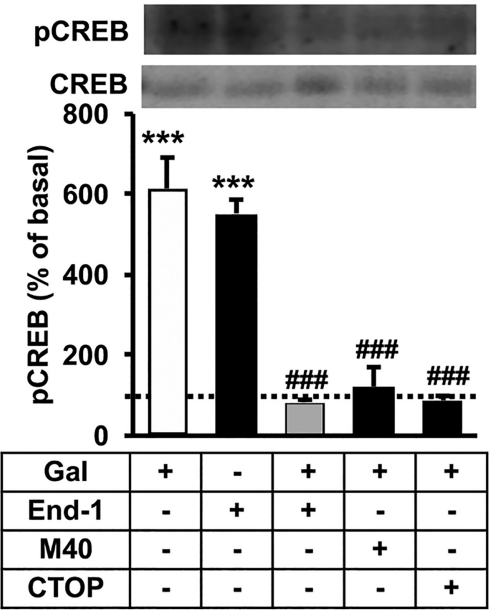

Figure 6. AKT and CREB phosphorylation by Gal1R-MOR heteromers in the rat VTA. AKT ( $A$ ) and CREB (B) phosphorylation were determined in rat VTA slices incubated for 20 min with medium, the MOR antagonist CTOP $(10 \mu \mathrm{M})$, or the Gal1R antagonist M40 $(10 \mu \mathrm{M})$ and treated for $12 \mathrm{~min}$ with medium, galanin (Gal, $1 \mu \mathrm{M}$ ), endomorphin-1 (End-1, $1 \mu \mathrm{M})$, or both; top, representative Western blots. Values are expressed as means \pm SEM (3-6 slices) of the percentage of values in untreated cells (dotted lines). Statistical differences were analyzed by one-way ANOVA followed by Newman-Keuls multiple comparison tests; ${ }^{*} p<0.05$ and ${ }^{* * *} p<0.001$, compared with untreated slices; ${ }^{\#} p<0.05$ and ${ }^{\# \# \#} p<0.001$, compared with slices only treated with the same concentration of galanin administered alone.

2015). Endomorfin-1 $(1 \mu \mathrm{M})$ produced a significant increase in basal ERK1/2 phosphorylation (Fig. $5 A$ ). Galanin also produced a significant increase, although less efficient than endomorphin- 1 at the same concentration $(1 \mu \mathrm{M}$; Fig. $5 A)$. On the other hand, coadministration of endomorphin- 1 and galanin did not produce a significant increase in basal ERK1/2 phosphorylation, indicating a strong and bidirectional negative cross talk in situ (Fig. 5A). That this negative cross talk is dependent on MOR-Gal1R heteromerization was demonstrated by the selective blockade with the MOR TAT-TM5 peptide, whereas the combination of both MOR TAT-TM1 plus MOR TAT-TM7 was ineffective (Fig. 5B). Furthermore, the MOR-Gal1R heteromerization-dependent cross-antagonism observed in transfected cells could also be demonstrated in rat VTA slices. The effect of galanin was completely counteracted by both M40 and CTOP, whereas that of endomorphin-1 was only significantly counteracted by CTOP (Fig. $5 C$ ). Notably, cross-antagonism of galanin with CTOP was selectively blocked with the MOR TAT-TM5 peptide, but not with the combination of both MOR TAT-TM1 plus MOR TATTM7 (Fig. 5D).

These results demonstrate that the previously reported ability of systemic administration of morphine to produce ERK1/2 phosphorylation in the VTA (Valjent et al., 2004; Hawes et al., 2008) can be related to a direct activation of MOR in the VTA that are largely forming heteromers with GallR. The possibility of other signaling pathways mediated by MOR-GallR heteromers in the VTA was also explored in situ by assessing AKT and CREB phosphorylation in rat VTA slices. To our knowledge, we could demonstrate for the first time the ability of the local activation of MOR and galanin receptors to induce activation of both signaling pathways and a strong and bidirectional negative cross talk (Fig. 6). Also, in both cases, a significant cross-antagonism between galanin and CTOP could be demonstrated (Fig. 6), which implies the identification of the biochemical properties of the MORGal1R heteromer.

Finally, we addressed a possible role of MOR-Gal1R heteromers in the modulation of dendritic dopamine release. Dendritic dopamine release by mesencephalic dopaminergic cells resembles that of the terminal regions, possessing a similar uptake mechanism and a finite releasable storage pool (Kita et al., 2009). Furthermore, local dopamine release in the VTA is a correlate of dopaminergic cell firing (Legault and Wise, 1999). For instance, local administration of a MOR agonist in the VTA has been previously shown to increase dopamine release both in the VTA (Chefer et al., 2009) and in its striatal terminal area, the nucleus accumbens (Spanagel et al., 1992). VTA dendritic dopamine release in vivo was determined with a recently introduced, especially designed infusion-microdialysis probe that allows the slow direct infusion of peptides within the sampling area, which can include peptidergic ligands and disruptive TAT-TM peptides (Navarro et al., 2015). Using this technique, we demonstrated the existence of functional heteromers of orexin and corticotropin-releasing factor receptors in the rat VTA (Navarro et al., 2015). As previously reported for another MOR agonist (DAMGO; Chefer et al., 2009), intra-VTA infusion of endomorphin-1 $(10 \mu \mathrm{M})$ produced a significant dendritic dopamine release (close to $100 \%$ increase in basal extracellular levels; Fig. $7 A$ ). Intra-VTA infusion of galanin $(10 \mu \mathrm{M})$ alone did not produce any significant effect but completely counteracted the effect of endomorphin-1 (Fig. 7A). Synthetic peptides were then used to demonstrate that these interactions between endomorphin- 1 and galanin depend on MOR-Gal1R heteromers. Intra-VTA infusion of the MOR TAT-TM5 peptide, but not MOR TAT-TM7 (60 $\mu \mathrm{M}$ in both cases), completely disrupted the ability of galanin to counteract the dopamine-releasing effect of endomorphin-1 (Fig. 7B). As control experiments, MOR TAT-TM5 did not modify the basal dopamine levels or endomorphin-1-induced dopamine release (Fig. 7C).

\section{Discussion}

The results of this study demonstrate (1) that MOR can form heteromers with Gal1R but not with Gal2R, (2) the existence of functionally significant MOR-GallR heteromers in the VTA, and (3) that this heteromer provides a main mechanism responsible for opioid-galanin antagonistic interactions. In fact, the results indicate that dopaminergic cell function in the VTA is modulated by a predominant population of MORs forming heteromers with Gal1R. Therefore, MOR-Gal1R constitutes an obvious target for the treatment of opioid use disorders.

The main challenge in the field of GPCR heteromers is the demonstration of their presence and functional significance in native tissues and, even more challenging, in vivo. The introduction of synthetic peptides with the capacity to disrupt the heteromer interface is providing a very valuable tool to determine the functional characteristics that depend on GPCR heteromerization. Sufficient experimental data have now accumulated showing that synthetic peptides with the same amino acid sequence of the interactive intracellular or TM domains of the different units (protomers) of GPCR heteromers constitute very selective and effective tools to disrupt their quaternary structure and, therefore, their biochemical properties (Azdad et al., 2009; He et al., 2011; Guitart et al., 2014; Bonaventura et al., 2015; Navarro et al., 2015; Viñals et al., 2015). Disrupting peptides are first applied in vitro, using biophysical techniques like $\mathrm{BiFC}$, to visualize their 
A

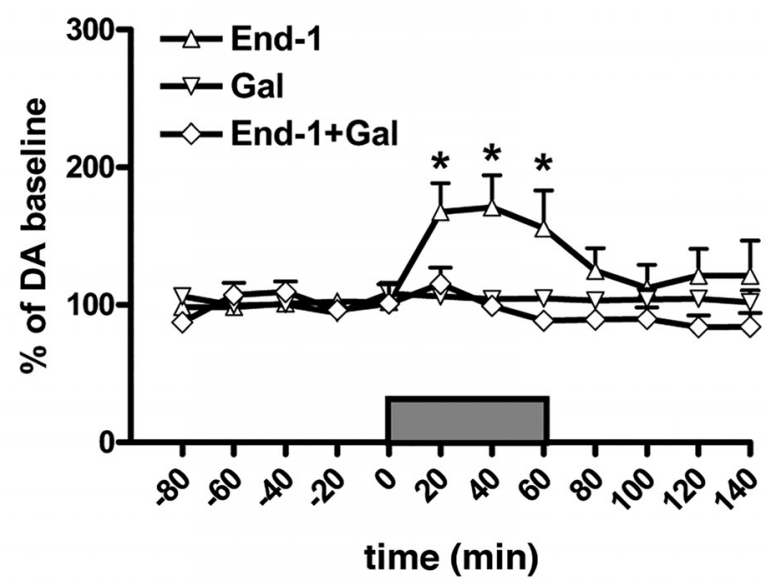

B

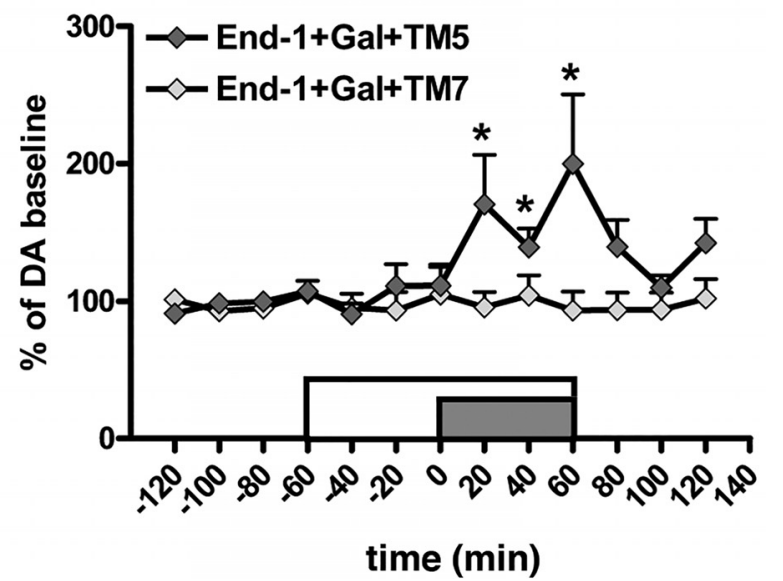

C

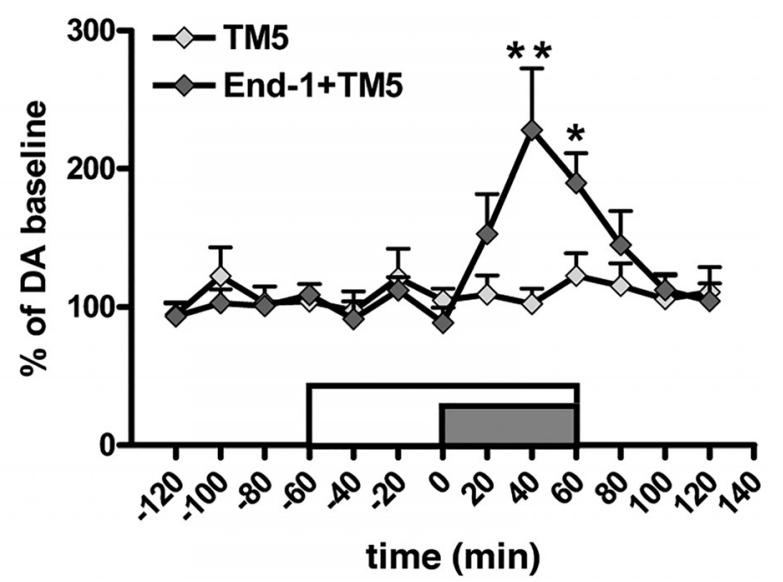

Figure 7. Modulation of dendritic dopamine release by Gal1R-MOR heteromers in the rat VTA. Dopamine (DA) levels in dialysates sampled from the VTA after slow infusion (1 $\mu \mathrm{l} / \mathrm{h}$; gray horizontal bar indicates the period of infusion) of endomorphin-1 (End-1, 10 $\mu \mathrm{M})$ and/or galanin (Gal, $10 \mu \mathrm{M})$ without $(\boldsymbol{A})$ or with $(\boldsymbol{B}, \boldsymbol{C})$ infusion $(1 \mu \mathrm{l} / \mathrm{h}$; white horizontal bar indicates the period of infusion) of MOR TAT-TM5 or MOR TAT-TM7 peptides $(60 \mu \mathrm{M})$. Values are means \pm SEM $(n=9-11)$ and are expressed as percentage of basal values (average of first 3 values before endomorphin-1 and/or galanin infusion, orexin- $A$ or (RF infusion). A repeated-measures ANOVA followed by Newman-Keuls multiple comparison tests; ${ }^{*} p<0.05$ and ${ }^{* *} p<0.01$, compared with the last basal values before endomorphin-1 and/or galanin infusion. ability to significantly distort the quaternary structure of the GPCR heteromer. Then, their selective ability to disrupt a specific biochemical effect of ligands binding to either protomer can then be used as a "biochemical fingerprint" to identify the GPCR heteromer in native tissues (Ferré et al., 2009). An even more conclusive demonstration can be achieved by directly probing the biochemical property of the heteromer with the in situ or in vivo application of the specific disruptive peptides.

In the present study, a peptide corresponding to MOR TM5 selectively disrupted MOR-Gal1R heteromerization in BiFC experiments and a negative cross talk at the level of MAPK signaling between the two MOR and Gal1R endogenous ligands endomorphin-1 and galanin in mammalian transfected cells. This negative cross talk implied the ability of galanin to counteract endomorphin-1-induced ERK1/2 phosphorylation, and its selective disruption by MOR TM5 implied its dependence on MOR-Gal1R heteromerization. The presence of functional MOR-Gall heteromers in the VTA could then be demonstrated by disclosing the same negative cross talk and its selective blockade with the MOR TM5 peptide in the native tissue, in rat VTA slices. MOR-Gal1R heteromers in the VTA therefore provide the mechanism for the previously described opioid-galanin antagonistic interaction on MAPK signaling in the VTA (Hawes et al., 2008). A further validation of the existence of MOR-Gal1 heteromers in the VTA was the demonstration of an additional property of the heteromer, a cross-antagonism, which constitutes a common biochemical property of GPCR heteromers (Ferré et al., 2014). The cross-antagonism, which implied the ability of the MOR antagonist CTOP to block galanin-induced ERK1/2 phosphorylation, was present in both transfected cells and in VTA slices. In both cases, its dependence on MOR-GallR heteromerization was demonstrated by its selective blockade with the MOR TM5 peptide. Furthermore, the same negative cross talk between endomorphin-1 and galanin and cross-antagonism between galanin and CTOP could be demonstrated with two additional signaling pathways, AKT and CREB phosphorylation, within the VTA. The complete counteractive effect of galanin on endomorphin-1-mediated signaling and of CTOP on galaninmediated signaling implies that a main population of both MOR and GallR in the VTA are, in fact, forming functional MORGal1R heteromers.

By applying our recently introduced infusion-microdialysis probe (Navarro et al., 2015), we could also demonstrate that MOR-Gal1R heteromers exert a main control of dendritic dopamine release in the VTA, since galanin completely antagonized endomorphin-1-induced dopamine release and this effect was selectively counteracted by the MOR TM5 peptide. These results demonstrate that an integration of opioid and galanin signals by MOR-Ga1R heteromers in the VTA determines the degree of activation of the dopaminergic cells. The exact localization of the heteromers still needs to be determined but could be either in the terminals of at least one of the main GABAergic afferents already known to be modulated by MOR, which include afferents from the striatal patch compartment and from the rostromedial tegmental nucleus or tail of the VTA (Barrot et al., 2012; Cui et al., 2014; Matsui et al., 2014), or in the soma or dendrites of the dopaminergic cells (Margolis et al., 2014).

The main outcome of the present study is that we have identified MOR-Gal1R heteromers as a main population of functional MOR localized in the VTA, which modulate dopaminergic cell activity. This provides a new mechanism by which galanin influences dopaminergic neurotransmission, adding to other previously described mechanisms that involve the hypothalamus 
(paraventricular nucleus), where galanin injections induced activation of VTA neurons and dopamine release in the nucleus accumbens (Rada et al., 1998; Karatayev et al., 2009). The introduction of GPCR heteromers as targets for drug development provides additional possibilities than just the targeting of one of the protomers (Ferré et al., 2014; Gomes et al., 2016). Therefore, the MOR-Gal1R heteromer should be viewed as a new target for the treatment of opioid use disorders. Using Ga1R ligands should allow a more specific targeting of MOR involved in the reinforcing effects of opioids. In fact, galanin receptors in the spinal cord are being considered as targets for pain medications, with evidence that galanin receptor agonists produce analgesic effects (Lang et al., 2015). This predicts that coadministration of MOR and Gal1R agonists can provide strong analgesia with low addictive consequences. But the significant modulation that the MOR-Gal1R heteromers exert on the control of dopaminergic cell function in the VTA could have broader implications for the treatment of other substance use disorders, as well as other dopamine-related neuropsychiatric disorders. In fact, there is already preclinical evidence for the efficacy of the systemic administration of the nonpeptidergic galanin receptor agonist galnon on morphine- and also psychostimulant-mediated reinforcing effects (Hawes et al., 2008; Narasimhaiah et al., 2009; Ogbonmwan et al., 2015). In summary, the present results demonstrate that heteromers of MOR and GalR in the VTA exert a very significant modulation of dopamine cell function and, therefore, these results may represent a significant discovery that provides the first step toward a clinical application. MOR-GalR1 heteromers in the VTA could constitute important targets for drug development in substance use disorders and maybe for obesity secondary to food addiction. The next step could be provided from additional preclinical experiments that address the longterm effects of morphine and galanin receptor agonists.

\section{References}

Azdad K, Gall D, Woods AS, Ledent C, Ferré S, Schiffmann SN (2009) Dopamine $\mathrm{D} 2$ andadenosineA2A receptors regulate NMDA-mediated excitation in accumbens neurons through A2A-D2 receptor heteromerization. Neuropsychopharmacology 34:972-986. CrossRef Medline

Barrot M, Sesack SR, Georges F, Pistis M, Hong S, Jhou TC (2012) Braking dopamine systems: a new GABA master structure for mesolimbic and nigrostriatal functions. J Neurosci 32:14094-14101. CrossRef Medline

Beer B, Erb R, Pavlic M, Ulmer H, Giacomuzzi S, Riemer Y, Oberacher H (2013) Association of polymorphisms in pharmacogenetic candidate genes (OPRD1, GAL, ABCB1, OPRM1) with opioid dependence in European population: a case-control study. PLoS One 8:e75359. CrossRef Medline

Bonaventura J, Navarro G, Casadó-Anguera V, Azdad K, Rea W, Moreno E, Brugarolas M, Mallol J, Canela EI, Lluís C, Cortés A, Volkow ND, Schiffmann SN, Ferré S, Casadó V (2015) Allosteric interactions between agonists and antagonists within the adenosine A2A receptor-dopamine D2 receptor heterotetramer. Proc Natl Acad Sci U S A 112:E3609-E36018. CrossRef Medline

Boughton CK, Murphy KG (2013) Can neuropeptides treat obesity? A review of neuropeptides and their potential role in the treatment of obesity. Br J Pharmacol 170:1333-1348. CrossRef Medline

Chefer VI, Denoroy L, Zapata A, Shippenberg TS (2009) Mu opioid receptor modulation of somatodendritic dopamine overflow: GABAergic and glutamatergic mechanisms. Eur J Neurosci 30:272-278. CrossRef Medline

Cui Y, Ostlund SB, James AS, Park CS, Ge W, Roberts KW, Mittal N, Murphy NP, Cepeda C, Kieffer BL, Levine MS, Jentsch JD, Walwyn WM, Sun YE, Evans CJ, Maidment NT, Yang XW (2014) Targeted expression of $\mu$-opioid receptors in a subset of striatal direct-pathway neurons restores opiate reward. Nat Neurosci 17:2542-2561. CrossRef Medline

DiLeone RJ, Taylor JR, Picciotto MR (2012) The drive to eat: comparisons and distinctions between mechanisms of food reward and drug addiction. Nat Neurosci 15:1330-1335. CrossRef Medline
Faget L, Osakada F, Duan J, Ressler R, Johnson AB, Proudfoot JA, Yoo JH, Callaway EM, Hnasko TS (2016) Afferent inputs to neurotransmitterdefined cell types in the ventral tegmental area. Cell Rep 15:2796-2808. CrossRef Medline

Ferré S, Baler R, Bouvier M, Caron MG, Devi LA, Durroux T, Fuxe K, George SR, Javitch JA, Lohse MJ, Mackie K, Milligan G, Pfleger KD, Pin JP, Volkow ND, Waldhoer M, Woods AS, Franco R (2009) Building a new conceptual framework for receptor heteromers. Nat Chem Biol 5:131134. CrossRef Medline

Ferré S, Casadó V, Devi LA, Filizola M, Jockers R, Lohse MJ, Milligan G, Pin JP, Guitart X (2014) G protein-coupled receptor oligomerization revisited: functional and pharmacological perspectives. Pharmacol Rev 66: 413-434. CrossRef Medline

Gomes I, Ayoub MA, Fujita W, Jaeger WC, Pfleger KD, Devi LA (2016) G protein-coupled receptor heteromers. Annu Rev Pharmacol Toxicol 56: 403-425. CrossRef Medline

Guitart X, Navarro G, Moreno E, Yano H, Cai NS, Sánchez-Soto M, KumarBarodia S, Naidu YT, Mallol J, Cortés A, Lluís C, Canela EI, Casadó V, McCormick PJ, Ferré S (2014) Functional selectivity of allosteric interactions within $G$ protein-coupled receptor oligomers: the dopamine D1-D3 receptor heterotetramer. Mol Pharmacol 86:417-429. CrossRef Medline

Gulya K, Kriván M, Nyolczas N, Sarnyai Z, Kovács GL (1988) Central effects of the potent and highly selective mu opioid antagonist D-Phe-Cys-TyrD-Trp-Orn-Thr-Pen-Thr-NH2 (CTOP) in mice. Eur J Pharmacol 150: 355-360. CrossRef Medline

Hawes JJ, Picciotto MR (2005) GalR1 and GalR2 antisera recognize bands in their respective knockout mice (erratum for JCN 479:410). J Comp Neurol 490:98-100. CrossRef

Hawes JJ, Brunzell DH, Narasimhaiah R, Langel U, Wynick D, Picciotto MR (2008) Galanin protects against behavioral and neurochemical correlates of opiate reward. Neuropsychopharmacology 33:1864-1873. CrossRef Medline

He SQ, Zhang ZN, Guan JS, Liu HR, Zhao B, Wang HB, Li Q, Yang H, Luo J, Li ZY, Wang Q, Lu YJ, Bao L, Zhang X (2011) Facilitation of $\mu$-opioid receptor activity by preventing $\delta$-opioid receptor-mediated codegradation. Neuron 69:120-131. CrossRef Medline

Jhou TC, Xu SP, Lee MR, Gallen CL, Ikemoto S (2012) Mapping of reinforcing and analgesic effects of the mu opioid agonist endomorphin-1 in the ventral midbrain of the rat. Psychopharmacology 224:303-312. CrossRef Medline

Karatayev O, Barson JR, Chang GQ, Leibowitz SF (2009) Hypothalamic injection of non-opioid peptides increases gene expression of the opioid enkephalin in hypothalamic and mesolimbic nuclei: possible mechanism underlying their behavioral effects. Peptides 30:2423-2431. CrossRef Medline

Kita JM, Kile BM, Parker LE, Wightman RM (2009) In vivo measurement of somatodendritic release of dopamine in the ventral tegmental area. Synapse 63:951-960. CrossRef Medline

Lang R, Gundlach AL, Holmes FE, Hobson SA, Wynick D, Hökfelt T, Kofler B (2015) Physiology, signaling, and pharmacology of galanin peptides and receptors: three decades of emerging diversity. Pharmacol Rev 67: 118-175. CrossRef Medline

Legault M, Wise RA (1999) Injections of N-methyl-D aspartate into the ventral hippocampus increase extracellular dopamine in the ventral tegmental area and nucleus accumbens. Synapse 31:241-249. CrossRef Medline

Levran O, Londono D, O’Hara K, Nielsen DA, Peles E, Rotrosen J, Casadonte P, Linzy S, Randesi M, Ott J, Adelson M, Kreek MJ (2008) Genetic susceptibility to heroin addiction: a candidate gene association study. Genes Brain Behav 7:720-729. CrossRef Medline

Margolis EB, Hjelmstad GO, Fujita W, Fields HL (2014) Direct bidirectional $\mu$-opioid control of midbrain dopamine neurons. J Neurosci 34:1470714716. CrossRef Medline

Matsui A, Jarvie BC, Robinson BG, Hentges ST, Williams JT (2014) Separate GABA afferents to dopamine neurons mediate acute action of opioids, development of tolerance, and expression of withdrawal. Neuron 82:1346-1356. CrossRef Medline

Matthes HW, Maldonado R, Simonin F, Valverde O, Slowe S, Kitchen I, Befort K, Dierich A, Le Meur M, Dollé P, Tzavara E, Hanoune J, Roques BP, Kieffer BL (1996) Loss of morphine-induced analgesia, reward ef- 
fect and withdrawal symptoms in mice lacking the mu-opioid-receptor gene. Nature 383:819-823. CrossRef Medline

McBride WJ, Murphy JM, Ikemoto S (1999) Localization of brain reinforcement mechanisms: intracranial self-administration and intracranial placeconditioning studies. Behav Brain Res 101:129-152. CrossRef Medline

Narasimhaiah R, Kamens HM, Picciotto MR (2009) Effects of galanin on cocaine-mediated conditioned place preference and ERK signaling in mice. Psychopharmacology (Berl) 204:95-102. CrossRef Medline

Navarro G, Quiroz C, Moreno-Delgado D, Sierakowiak A, McDowell K, Moreno E, Rea W, Cai NS, Aguinaga D, Howell LA, Hausch F, Cortés A, Mallol J, Casadó V, Lluís C, Canela EI, Ferré S, McCormick PJ (2015) Orexin-corticotropin-releasing factor receptor heteromers in the ventral tegmental area as targets for cocaine. J Neurosci 35:6639-6653. CrossRef Medline

Ogbonmwan YE, Sciolino NR, Groves-Chapman JL, Freeman KG, Schroeder JP, Edwards GL, Holmes PV, Weinshenker D (2015) The galanin receptor agonist, galnon, attenuates cocaine-induced reinstatement and dopamine overflow in the frontal cortex. Addict Biol 20:701-713. CrossRef Medline

Palmiter RD (2007) Is dopamine a physiologically relevant mediator of feeding behavior? Trends Neurosci 30:375-381. CrossRef Medline

Picciotto MR (2008) Galanin and addiction. Cell Mol Life Sci 65:18721879. CrossRef Medline

Rada P, Mark GP, Hoebel BG (1998) Galanin in the hypothalamus raises dopamine and lowers acetylcholine release in the nucleus accumbens: a possible mechanism for hypothalamic initiation of feeding behavior. Brain Res 798:1-6. CrossRef Medline

Spanagel R, Herz A, Shippenberg TS (1992) Opposing tonically active endogenous opioid systems modulate the mesolimbic dopaminergic pathway. Proc Natl Acad Sci U S A 89:2046-2050. CrossRef Medline

Valjent E, Pagès C, Hervé D, Girault JA, Caboche J (2004) Addictive and non-addictive drugs induce distinct and specific patterns of ERK activation in mouse brain. Eur J Neurosci 19:1826-1836. CrossRef Medline

Viñals X, Moreno E, Lanfumey L, Cordomí A, Pastor A, de La Torre R, Gasperini P, Navarro G, Howell LA, Pardo L, Lluís C, Canela EI, McCormick PJ, Maldonado R, Robledo P (2015) Cognitive impairment induced by Delta9-tetrahydrocannabinol occurs through heteromers between cannabinoid CB1 and serotonin 5-HT2A receptors. PLoS Biol 13:e1002194. CrossRef Medline

Volkow ND, Wang GJ, Baler RD (2011) Reward, dopamine and the control of food intake: implications for obesity. Trends Cogn Sci 15:37-46. CrossRef Medline

Webling KE, Runesson J, Bartfai T, Langel U (2012) Galanin receptors and ligands. Front Endocrinol 3:146. CrossRef Medline

Wise RA (1989) Opiate reward: sites and substrates. Neurosci Biobehav Rev 13:129-133. CrossRef Medline

Zachariou V, Parikh K, Picciotto MR (1999) Centrally administered galanin blocks morphine place preference in the mouse. Brain Res 831:33-42. CrossRef Medline

Zachariou V, Brunzell DH, Hawes J, Stedman DR, Bartfai T, Steiner RA, Wynick D, Langel U, Picciotto MR (2003) The neuropeptide galanin modulates behavioral and neurochemical signs of opiate withdrawal. Proc Natl Acad Sci U S A 100:9028-9033. CrossRef Medline

Zadina JE, Hackler L, Ge LJ, Kastin AJ (1997) A potent and selective endogenous agonist for the mu-opiate receptor. Nature 386:499-502. CrossRef Medline

Zangen A, Ikemoto S, Zadina JE, Wise RA (2002) Rewarding and psychomotor stimulant effects of endomorphin-1: anteroposterior differences within the ventral tegmental area and lack of effect in nucleus accumbens. J Neurosci 22:7225-7233. Medline 